\title{
Tracing groundwater salinization processes in coastal aquifers: a hydrogeochemical and isotopic approach in the Na-Cl brackish waters of northwestern Sardinia, Italy
}

\author{
G. Mongelli ${ }^{1}$, S. Monni ${ }^{2}$, G. Oggiano ${ }^{2}$, M. Paternoster ${ }^{1}$, and R. Sinisi ${ }^{2}$ \\ ${ }^{1}$ Department of Sciences, Campus di Macchia Romana, University of Basilicata, 85100 Potenza, Italy \\ ${ }^{2}$ Department of Science for Nature and Environmental Resources, University of Sassari, 07100 Sassari, Italy \\ Correspondence to: M. Paternoster (michele.paternoster@unibas.it)
}

Received: 7 January 2013 - Published in Hydrol. Earth Syst. Sci. Discuss.: 24 January 2013

Revised: 31 May 2013 - Accepted: 3 June 2013 - Published: 24 July 2013

\begin{abstract}
Throughout the Mediterranean, salinization threatens water quality, especially in coastal areas. This salinization is the result of concomitant processes related to both seawater intrusion and water-rock interaction, which in some cases are virtually indistinguishable. In the Nurra region of northwestern Sardinia, recent salinization related to marine water intrusion has been caused by aquifer exploitation. However, the geology of this region records a long history from the Palaeozoic to the Quaternary, and is structurally complex and comprises a wide variety of lithologies, including Triassic evaporites. Determining the origin of the saline component of the Jurassic and Triassic aquifers in the Nurra region may provide a useful and more general model for salinization processes in the Mediterranean area, where the occurrence of evaporitic rocks in coastal aquifers is a common feature. In addition, due to intensive human activity and recent climatic change, the Nurra has become vulnerable to desertification and, in common with other Mediterranean islands, surface water resources periodically suffer from severe shortages. With this in mind, we report new data regarding brackish and surface waters (outcrop and lake samples) of the $\mathrm{Na}-\mathrm{Cl}$ type from the Nurra region, including major ions and selected trace elements (B, $\mathrm{Br}, \mathrm{I}$, and $\mathrm{Sr}$ ), in addition to isotopic data including $\delta^{18} \mathrm{O}, \delta \mathrm{D}$ in water, and $\delta^{34} \mathrm{~S}$ and $\delta^{18} \mathrm{O}$ in dissolved $\mathrm{SO}_{4}$. To identify the origin of the salinity more precisely, we also analysed the mineralogical and isotopic composition of Triassic evaporites. The brackish waters have $\mathrm{Cl}$ contents of up to $2025 \mathrm{mg} \mathrm{L}^{-1}$, and the ratios between dissolved ions and $\mathrm{Cl}$, with the exception of the $\mathrm{Br} / \mathrm{Cl}$ ratio, are not those expected on the basis of simple mixing between
\end{abstract}

rainwater and seawater. The $\delta^{18} \mathrm{O}$ and $\delta \mathrm{D}$ data indicate that most of the waters fall between the regional meteoric water line and the global meteoric water line, supporting the conclusion that they are meteoric in origin. A significant consequence of the meteoric origin of the Na-Cl-type water studied here is that the $\mathrm{Br} / \mathrm{Cl}$ ratio, extensively used to assess the origin of salinity in fresh water, should be used with care in carbonate aquifers that are near the coast. Overall, $\delta^{34} \mathrm{~S}$ and $\delta^{18} \mathrm{O}$ levels in dissolved $\mathrm{SO}_{4}$ suggest that water-rock interaction is responsible for the $\mathrm{Na}-\mathrm{Cl}$ brackish composition of the water hosted by the Jurassic and Triassic aquifers of the Nurra, and this is consistent with the geology and lithological features of the study area. Evaporite dissolution may also explain the high $\mathrm{Cl}$ content, as halite was detected within the gypsum deposits. Finally, these $\mathrm{Na}-\mathrm{Cl}$ brackish waters are undersaturated with respect to the more soluble salts, implying that in a climate evolving toward semi-arid conditions, the salinization process could intensify dramatically in the near future.

\section{Introduction}

In the Mediterranean, the demand for good quality water is rapidly increasing, but the process of salinization (e.g. Petalas and Lambrakis, 2006; El Yaouti et al., 2009; Ghiglieri et al., 2012; Sdao et al., 2012) threatens the exploitation of additional water resources such as groundwater. Salinization of aquifers in coastal areas is the result of concomitant processes related to both seawater intrusion and 
water-rock interaction, which in some cases are almost indistinguishable. In Sardinia, the Nurra region (in the northwest of the island) has a coastline that stretches for up to $80 \mathrm{~km}$ (Fig. 1), and salinization due to seawater intrusion has recently been identified, resulting from aquifer exploitation (Ghiglieri et al., 2012). The geology of the Nurra records a long history from the Palaeozoic to the Quaternary, resulting in its complex structure and varied lithologies, including Variscan low-grade metamorphic basement consisting of phyllites, quartzites, and metabasites, Lower-Middle Permian continental sediments and volcanites, Middle Triassic to Cretaceous evaporites and shallow-marine carbonate, Lower Miocene ignimbrites, alluvial deposits of Messinian age, and alluvial and eolian Quaternary deposits (Mameli et al., 2007; Mongelli et al., 2012).

In the Nurra, notwithstanding the importance of local groundwater as the main source of good quality water, exploitation has been uncontrolled, and, due to intensive human activity and recent climatic change, the area has become vulnerable to desertification (Ghiglieri et al., 2006). As a consequence, increasing demand for water has resulted in periodic shortages in surface water resources, in common with other Mediterranean islands (Ghiglieri et al., 2009). Chemical data available for the Nurra aquifers (Ghiglieri et al., 2009) show that these groundwaters are affected by significant chemical variability (e.g. TDS (total dissolved solid) values from 600 to $4000 \mathrm{mg} \mathrm{L}^{-1}, \mathrm{Cl}$ concentrations from 3 to $76 \mathrm{mg} \mathrm{L}^{-1}$ , and $\mathrm{SO}_{4}$ concentrations from 0.2 up to $40 \mathrm{mg} \mathrm{L}^{-1}$ ). This variability indicates that various geochemical processes may affect the composition of the resource. Ghiglieri et al. (2009) suggested that the initial chemical composition of source water was conditioned by water-rock interactions, including ion exchange with hydrothermal minerals and clays, and incongruent dissolution of dolomite.

These findings, in addition to the importance of the water resource and its role as a strategic reserve in a climate evolving towards semi-arid conditions, indicate the need for a detailed study of the processes that determine the hydrogeochemistry of the Nurra groundwater and its quality, based on identification of the sources of the ions responsible for the high salinity. It may then be possible to use the Nurra case study as a model for coastal aquifers hosted in Mesozoic carbonate-evaporite platforms. In fact, the origin of the saline component of groundwaters is difficult to assess using only chemical data, whereas combining chemical and isotopic composition data can enhance our understanding of the processes that cause salinization of continental waters (e.g. Faye et al., 2005; Bouchaou et al., 2008; Gattacceca et al., 2009). With this in mind, we report here new data on brackish waters of the $\mathrm{Na}-\mathrm{Cl}$ type from the Nurra, including major ions and selected trace elements $(\mathrm{B}, \mathrm{Br}, \mathrm{I}$, and $\mathrm{Sr}$ ) and isotopic data, including $\delta^{18} \mathrm{O}$ and $\delta \mathrm{D}$ in water, and $\delta^{34} \mathrm{~S}$ and $\delta^{18} \mathrm{O}$ in dissolved $\mathrm{SO}_{4}$. To determine the origin of the salinity more precisely, we also analysed the mineralogical and isotopic compositions $\left(\delta^{34} \mathrm{~S}\right.$ and $\left.\delta^{18} \mathrm{O}\right)$ of Nurra Triassic evaporites.

\section{Geological setting and groundwater circulation}

The structural framework of northwestern Sardinia is derived mainly from its Mesozoic and Tertiary tectonic evolution (Combes et al., 1993; Mameli et al., 2007), and is related to the Bedoulian movements, the Pyrenean phase, and the North Apennine collision followed by the opening of the Ligure-Provencal back-arc basin (Carmignani et al., 2004; Mameli et al., 2007; Oggiano et al., 2009). The cover rocks are affected by folds and thrusts that trend NE-SW. Evaporites commonly occur as décollement horizons and are exposed in the cores of anticlines and/or on décollement surfaces. Since the Burdigalian, the area has been subjected to an extensional tectonic regime related to the opening of the Liguro-Provencal Basin, followed by moderate uplift during the Pliocene (Malinverno and Ryan, 1986).

As a whole, the Nurra region consists of a structural high that represents the uplifted section of a wide block, tilted to the east. To the west, the Nurra borders the eastern passive margin of the Liguro-Provencal back-arc basin, while to the east it abuts the edge of a $\mathrm{N}-\mathrm{S}$ trending Miocene half-graben, i.e. the Porto Torres half-graben (Thomas and Gennessaux, 1986; Funedda et al., 2000). The Mesozoic and Cenozoic structural evolution of the region resulted in thin-skinned deformation, with the Mesozoic cover represented by a sequence of limestones, dolostones and, to a lesser extent, marlstones and evaporites, which deformed independently from the Palaeozoic basement that outcrops in the westernmost part of the region. Overall, the older rock sequences are progressively exposed westwards.

The Middle Triassic succession in the Nurra rests on red beds of Permo-Triassic age and consists mainly of pure dolostones and limestones, with clay-rich beds occurring within the Triassic deposits as marly limestones and clayey gypsum deposits. Marls also occur in the Early and Late Jurassic strata, the former associated with dark Liassic limestone with euxinic facies, and the latter with the typical lagoonallacustrine Purbeckian facies (Pecorini, 1969). The majority of the Jurassic succession consists of limestones and dolostones with a thickness exceeding $700 \mathrm{~m}$. The Jurassic beds host the most important aquifer in the area (Ghiglieri et al., 2009). The Lower Cretaceous is represented by pure Urgonian limestones, while the Upper Cretaceous lies unconformably on the Urgonian calcarenites along a bauxite layer, and consists of Hippurites-bearing limestones and marls of Late Cretaceous age (Coniacian to Maastrichtian). The whole Cretaceous sequence has a maximum thickness of about $400 \mathrm{~m}$ and locally hosts perched aquifers outside of the study area.

Within the study area, the Mesozoic rocks are locally capped by Tertiary pyroclastic flows and by alluvial deposits 


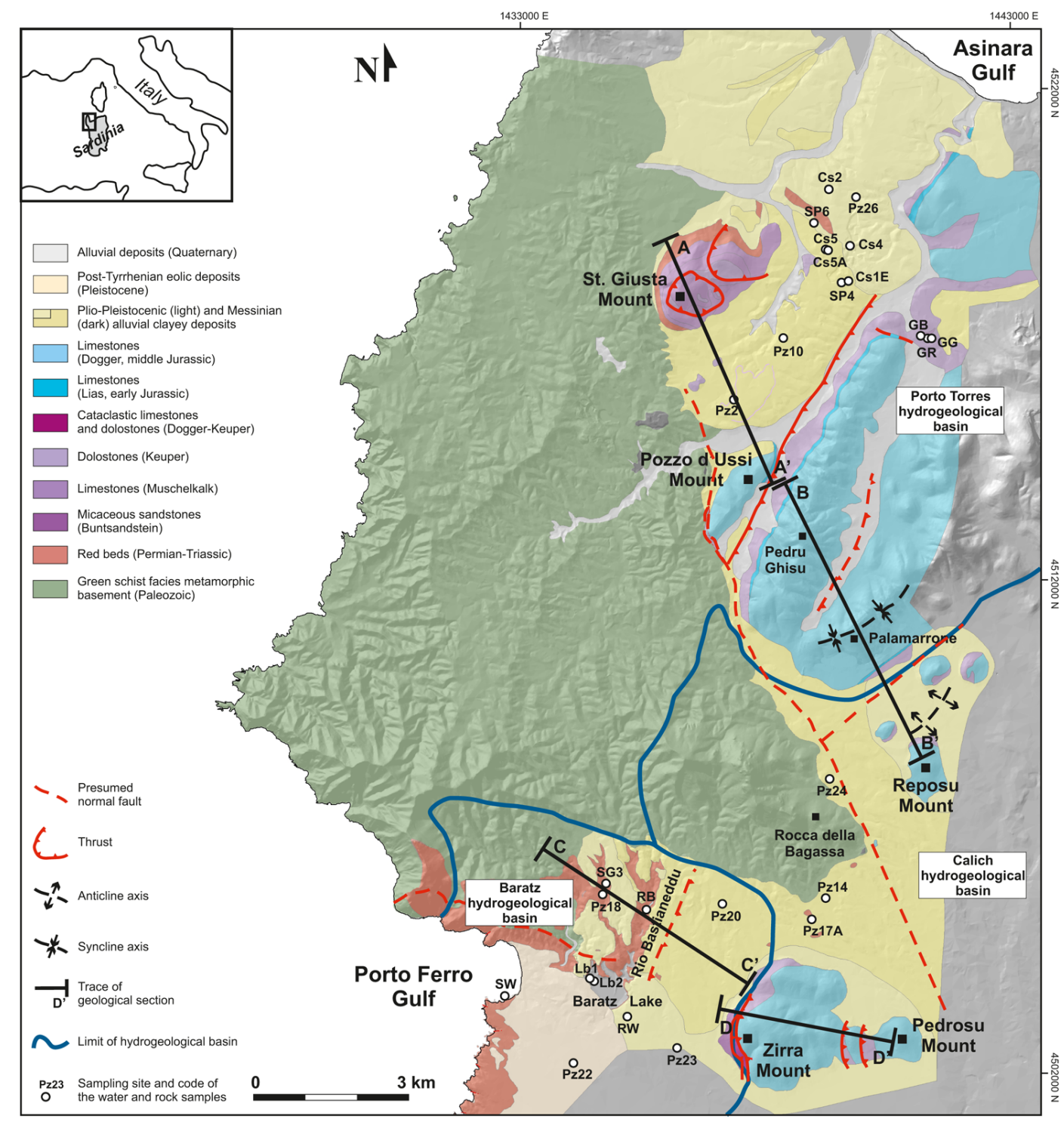

Fig. 1. Digital terrain model (DTM)-based geological map of investigated area. The localization of sampling sites and code of the analysed water and rock sample are shown. The limits of hydrogeological basins are from Ghiglieri et al. (2009). See text for further details.

of Messinian age, consisting of alluvial sequences 30 to $80 \mathrm{~m}$ thick composed mostly of clays and matrix-supported conglomerates. This deposit constitutes an important hydrogeological unit for the northwestern part of the Nurra region as it acts as an aquitard that seals the confined aquifers hosted by the Mesozoic succession (see the cross section labelled A-A' in Fig. 2).

Within this geological framework, several hydrogeological units were identified by Ghiglieri et al. (2009). In particular, in the study area, the main aquifers occur in the thick Jurassic carbonate sequence that corresponds to the Jurassic aquifer proposed by Ghiglieri et al. (2009), and within the carbonate and evaporitic succession of Triassic age that corresponds to the Triassic aquifer of Ghiglieri et al. (2009). A hydrogeological unit represented by the metamorphic basement rocks, and located on the west coast of the Nurra district, acts as a partial recharge area for these aquifers.

The area sampled was mostly within the Porto Torres hydrogeological basin, where the Jurassic aquifer has either reduced thickness in comparison with the Calich basin (Ghiglieri et al., 2009), or is absent to the west. The groundwater flow in this basin is towards the northern shore (Asinara Gulf), whereas in the Calich basin it is to the south. The two hydrogeological systems are separated by a structural high towards which the axes of the main structures converge (B-B' in Fig. 2).

Detailed geological mapping of the area identified another structural high between Monte Zirra and Rocca della 


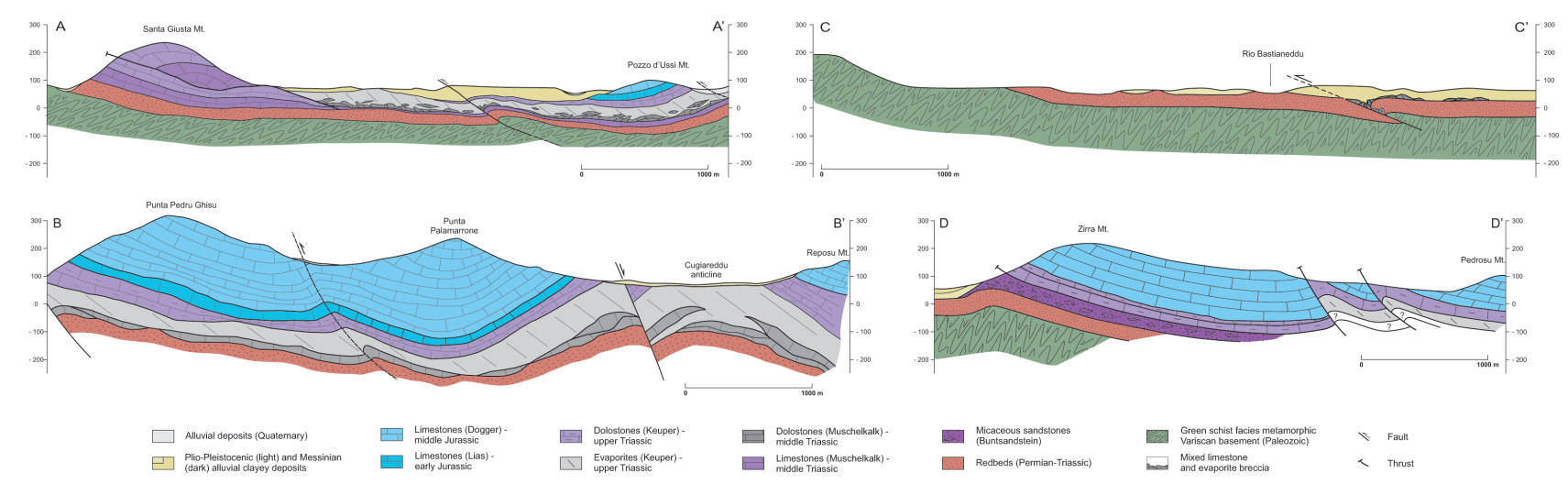

Fig. 2. A-A', B-B', C-C' and D-D' geological sections of Fig. 1. See text for further details.

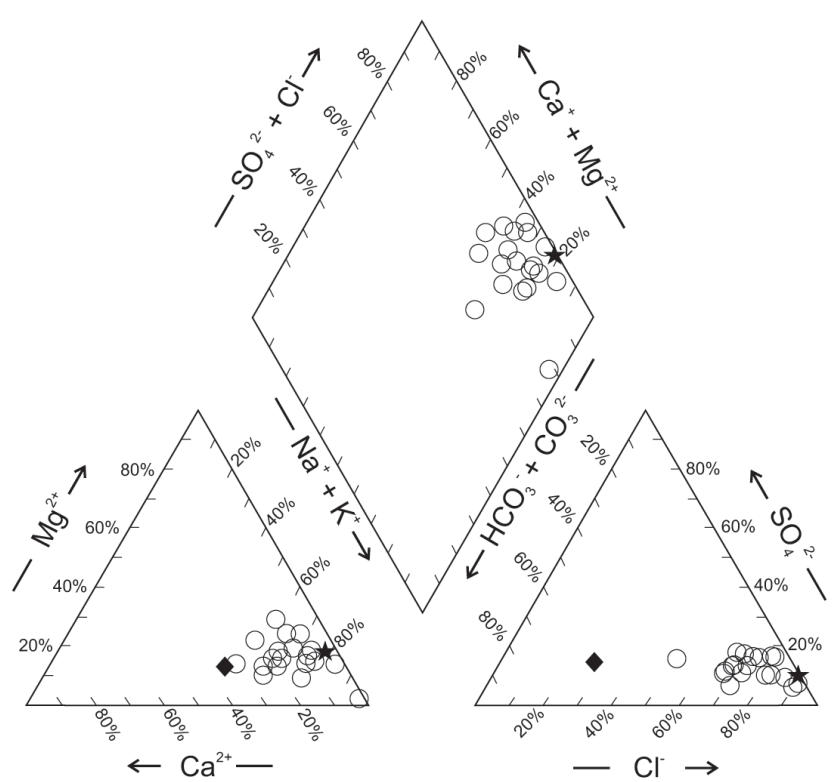

Fig. 3. Relative amounts of major ions analysed in sampled waters plotted in a Piper plot. Filled diamonds indicate rainwater; filled stars indicate seawater.

Bagassa, which acts as a geological watershed between the Calich basin to the east and a small hydrogeological basin (Baratz hydrogeological basin) flowing towards the western coast of the Nurra (Porto Ferro gulf). Water samples were collected from the western section of the Porto Torres hydrogeological basin and the Baratz hydrogeological basin, within the Triassic aquifer hosted in the carbonate rocks, cataclastic evaporites, and red sandstone (red beds). These saturated deposits are recharged by both the Palaeozoic metamorphic basement to the west and by the Jurassic carbonate hills to the east.

\section{Sampling and analysis}

Water samples from 19 springs and wells, and 2 further samples from Baratz Lake, were collected in September and October of 2011 in the coastal areas of the Nurra district (Fig. 1). In addition, a seawater sample was collected from a site $0.1 \mathrm{~km}$ from the Porto Ferro coastline, and a rainwater sample was collected in September 2011 near the Baratz Lake site (in the south of the Nurra region). Many of the sampled springs and wells supply drinking water and irrigation. We used a high-resolution multiparametric probe (Hach HQ 30d) to measure the $\mathrm{pH}$, temperature, and electrical conductivity (EC) of each sample. All water samples were filtered through $0.45 \mu \mathrm{m}$ MF-Millipore membrane filters in the field, and then stored in high-density polyethylene bottles (50 and $100 \mathrm{~mL}$ ). Prior to their use, these bottles were cleaned with nitric acid $\left(\mathrm{HNO}_{3}\right)$ and then rinsed with deionized water. The bottles were filled to the top with water, capped without leaving any head space, stored in a refrigerated container $\left(\mathrm{ca} .4^{\circ} \mathrm{C}\right.$ ) during transportation to the laboratory, and then kept cool until analysis.

At each sampling site, two water samples (for cation analyses) were collected and acidified with Suprapur ${ }^{\circledR} \mathrm{HNO}_{3}$ $(1 \% \mathrm{v} / \mathrm{v})$ after filtration to prevent metal precipitation. For anion analysis, an unacidified $100 \mathrm{~mL}$ sample was collected. Alkalinity was determined in the field by titration with $\mathrm{HCl}$ $(0.1 \mathrm{M})$. Cation concentrations ( $\mathrm{Ca}, \mathrm{Mg}, \mathrm{Na}, \mathrm{K}$, and $\mathrm{Sr}$ ) were analysed using inductively coupled plasma-optical emission spectroscopy (ICP-OES) at the Activation Laboratory of Actlabs (Canada) with a precision better than $\pm 5 \%$. Anion concentrations were determined for $\mathrm{Cl}, \mathrm{SO}_{4}, \mathrm{NO}_{3}$, and $\mathrm{Br}$ using ion chromatography (Dionex CX-100), and minor elements (I and B) were determined using inductively coupled plasma-mass spectrometry (ICP-MS). Ionic balance was computed for each sample taking into account major species. All samples exhibited imbalances of less than $5 \%$. Several certified reference materials (NIST 1643e, NIST 1640E, and SLRS-5) were processed and analysed along with the samples to assess the accuracy of analyses, and the 


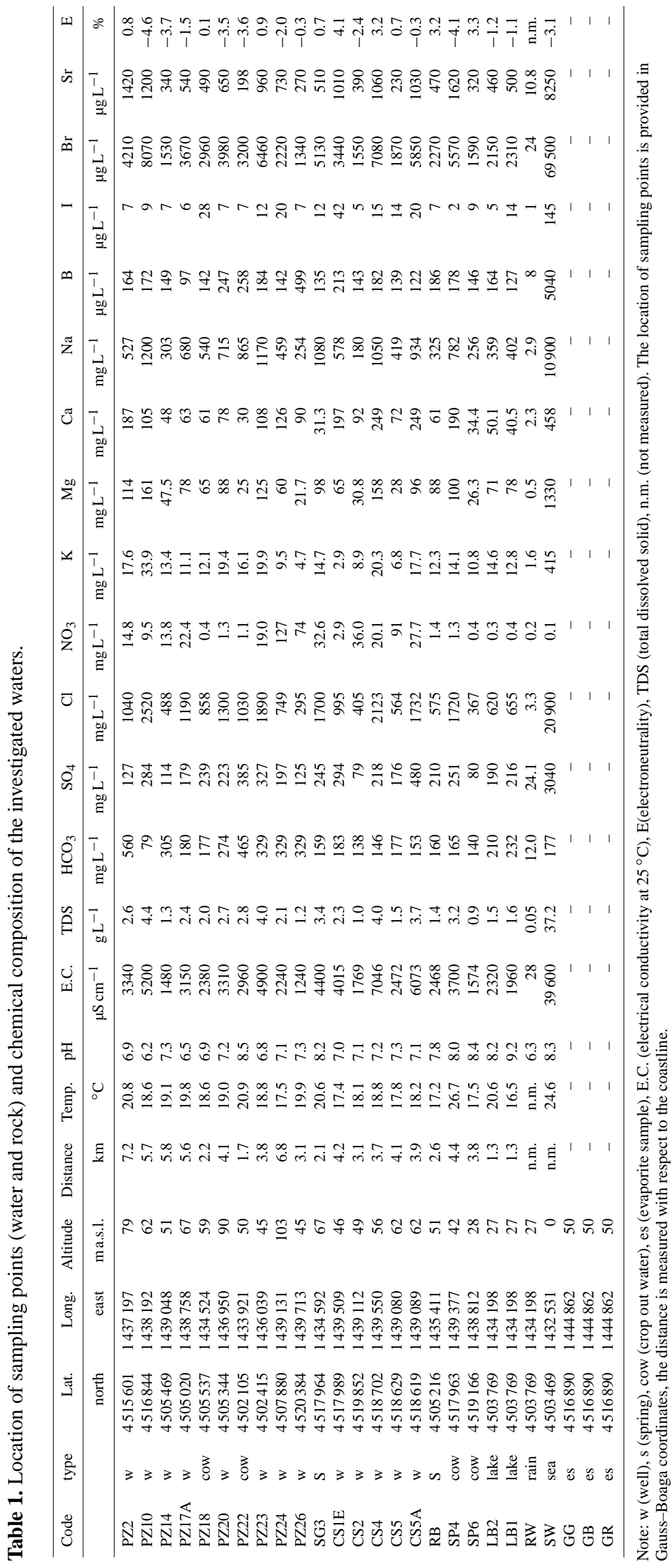


Table 2. Isotopic data and saturation indexes for a few mineralogical phases.

\begin{tabular}{|c|c|c|c|c|c|c|c|c|}
\hline Code & $\delta^{34} \mathrm{~S}_{-} \mathrm{SO}_{4}$ & $\delta^{18} \mathrm{O}-\mathrm{SO}_{4}$ & $\delta^{18} \mathrm{O}$ & $\delta \mathrm{D}$ & SI & SI & SI & SI \\
\hline & $\%$ V-CDT & $\%$ V-CDT & $\%$ VSMOW & $\%$ VSMOW & Gypsum & Halite & Anhydrite & Sylvite \\
\hline PZ2 & 17.4 & 12.2 & -6.2 & -34 & -1.7 & -5.0 & -1.8 & -6.0 \\
\hline PZ10 & 20.3 & 13.0 & -6.4 & -35 & -1.7 & -4.3 & -1.9 & -5.4 \\
\hline PZ14 & 14.9 & 12.7 & -5.6 & -34 & -2.1 & -5.5 & -2.2 & -6.4 \\
\hline PZ17A & 17.0 & 13.3 & -5.9 & -36 & -1.9 & -4.8 & -2.1 & -6.2 \\
\hline PZ18 & 18.6 & 14.0 & -5.0 & -30 & -1.7 & -5.0 & -1.9 & -6.3 \\
\hline PZ20 & 15.5 & 10.2 & -6.3 & -36 & -1.8 & -4.7 & -1.9 & -5.9 \\
\hline PZ22 & 20.5 & 13.9 & -5.1 & -32 & -1.9 & -4.7 & -2.1 & -6.1 \\
\hline PZ23 & 19.5 & 13.0 & -6.1 & -36 & -1.6 & -4.4 & -1.8 & -5.8 \\
\hline PZ24 & 15.5 & 10.7 & -6.4 & -39 & -1.5 & -5.1 & -1.7 & -6.4 \\
\hline PZ26 & 16.2 & 10.7 & -5.8 & -34 & -1.7 & -5.8 & -1.9 & -7.1 \\
\hline SG3 & 20.2 & 13.7 & -6.5 & -38 & -2.2 & -4.4 & -2.3 & -5.9 \\
\hline CS1E & 18.4 & 12.0 & -5.7 & -33 & -1.2 & -4.9 & -1.4 & -6.8 \\
\hline $\mathrm{CS} 2$ & 15.6 & 10.2 & -6.6 & -36 & -1.9 & -5.8 & -2.1 & -6.7 \\
\hline CS4 & 18.0 & 13.2 & -6.1 & -34 & -1.4 & -4.4 & -1.6 & -5.7 \\
\hline CS5 & 18.9 & 11.8 & -6.4 & -36 & -1.7 & -5.3 & -1.9 & -6.7 \\
\hline CS5A & 20.9 & 14.1 & -6.0 & -35 & -1.1 & -4.5 & -1.2 & -5.8 \\
\hline $\mathrm{RB}$ & 14.5 & 9.6 & -6.0 & -33 & -1.8 & -5.4 & -1.9 & -6.4 \\
\hline SP4 & 18.9 & 12.7 & -3.3 & -25 & -1.4 & -4.6 & -1.6 & -5.9 \\
\hline SP6 & 15.8 & 9.8 & -3.1 & -22 & -2.3 & -5.7 & -2.4 & -6.6 \\
\hline LB2 & 15.5 & 10.9 & -2.4 & -18 & -1.9 & -5.3 & -2.1 & -6.3 \\
\hline LB1 & 15.3 & 12.2 & -2.1 & -16 & -1.9 & -5.2 & -2.1 & -6.3 \\
\hline RW & 3.7 & 10.0 & -5.5 & -29 & - & - & - & - \\
\hline SW & 21.5 & 10.1 & 1.1 & 5 & - & - & - & - \\
\hline GG & 14.4 & 11.6 & n.m. & n.m. & - & - & - & - \\
\hline GB & 14.9 & 11.2 & n.m. & n.m. & - & - & - & - \\
\hline GR & 15.4 & 10.4 & n.m. & n.m. & - & - & - & - \\
\hline
\end{tabular}

Note: n.m. = not measured; saturation indexes were performed using GWB®8.0 with the thermodynamic database thermoddem.dat.

results from these reference materials agree with the certified values.

For oxygen isotopic analysis, about $2 \mathrm{~mL}$ of each sample was equilibrated with $\mathrm{CO}_{2}$ by shaking for $6 \mathrm{~h}$ at $25^{\circ} \mathrm{C}$ (Epstein and Mayeda, 1953). For the hydrogen isotopic analysis, metallic zinc was used to produce hydrogen gas by the zinc reduction method (Coleman et al., 1982). Stable isotope ratios were measured on a dual inlet Finnigan Delta Plus IRMS with an analytical precision of better than $0.2 \%$ for oxygen and $1 \%$ for hydrogen. Five water samples calibrated with respect to the VSMOW (Vienna Standard Mean Ocean Water) and GISP (Greenland Ice Sheet Precipitation) international standards were used as working standards. For the sulfur isotopic analysis, dissolved $\mathrm{SO}_{4}$ was precipitated as $\mathrm{BaSO}_{4}$ by the addition of $\mathrm{BaCl}_{2}$. The sample was then acidified to $\mathrm{pH}<2$ to dissolve any precipitated $\mathrm{BaCO}_{3}$. For $\delta^{34} \mathrm{~S}$ analysis, $\mathrm{SO}_{2}$ gas was prepared using the method of Yanagisawa and Sakai (1983). The isotopic composition of sulfur was determined using continuous flow-elemental analysisisotope ratio mass spectrometry (CF-EA-IRMS) at the Isotope Science Laboratory of the University of Calgary (ISLUofC). The analytical precision was $0.3 \%$ for $\delta^{34} \mathrm{~S}_{-} \mathrm{SO}_{4}$ and $0.5 \%$ for $\delta^{18} \mathrm{O}_{-} \mathrm{SO}_{4}$. Isotopic results were expressed as \%o deviation ( $\delta$ notation) relative to international standards as follows: VSMOW for ${ }^{18} \mathrm{O}$ and ${ }^{2} \mathrm{H}$, and V-CDT for ${ }^{34} \mathrm{~S}$ and ${ }^{18} \mathrm{O}$ in dissolved $\mathrm{SO}_{4}$ (Gonfiantini et al., 1995).

Finally, to properly evaluate the water-rock interaction processes, three evaporites were sampled and analysed for mineralogical and isotopic composition. The mineralogy of bulk samples was obtained by X-ray powder diffraction (XRPD) using a Rigaku Rint 2200 diffractometer with $\mathrm{CuK} \alpha$ radiation at $40 \mathrm{kV}$ and $30 \mathrm{~mA}$.

\section{Results and discussion}

\subsection{Mineralogical and isotopic features of the Nurra evaporites}

The mineralogy and isotopic composition of three samples from the Upper Triassic evaporites were analysed (Table 2 and samples GR, GG, and GB in Fig. 1). The rocks were collected at the transition between the Muschelkalk carbonates and the Keuper evaporites, where the sequence comprises alternations of grey, white, and red evaporite deposits. All of the evaporites were composed of gypsum; in the case of the grey deposits, XRD analysis revealed the presence of halite and quartz as minor components. The evaporites have $\delta^{34} \mathrm{~S}$ $\mathrm{SO}_{4}$ values between +14.4 and $+15.4 \%$, and $\delta^{18} \mathrm{O}_{-} \mathrm{SO}_{4}$ 

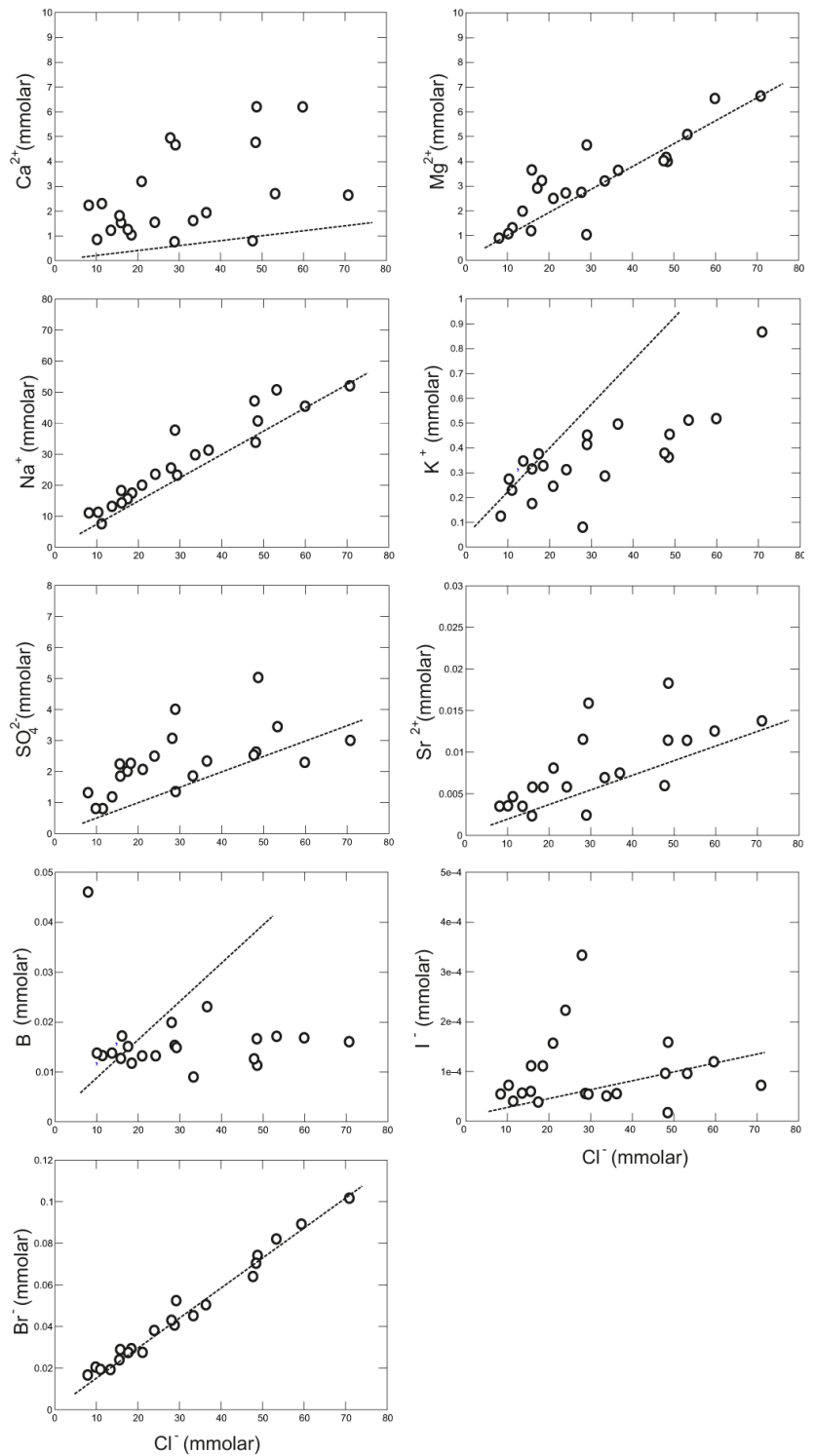

Fig. 4. Binary plots between chlorine and selected ions (expressed in $\mathrm{mmol} \mathrm{L}^{-1}$ ) in the analysed water samples. The lines indicate mixing between marine and rainwater samples.

values between +10.4 and $+11.6 \%$. These values are in the range covered by the isotopic composition of marine evaporites of Upper Triassic age, i.e. +10.9 to $+18.3 \%$ (Krouse and Grinenko, 1991, and references therein).

\subsection{Water chemistry}

Temperature, $\mathrm{pH}, \mathrm{EC}\left(\right.$ at $25^{\circ} \mathrm{C}$ ) values, and the chemical composition of the water samples are provided in Table 1 . The $\mathrm{pH}$ values range between 6.2 and 8.5 , with the exception of the Baratz Lake samples (LB1 and LB2) that have higher values (9.2 and 8.2 , respectively). Water temperature was between 16.5 and $20.9^{\circ} \mathrm{C}$ with the exception of sample

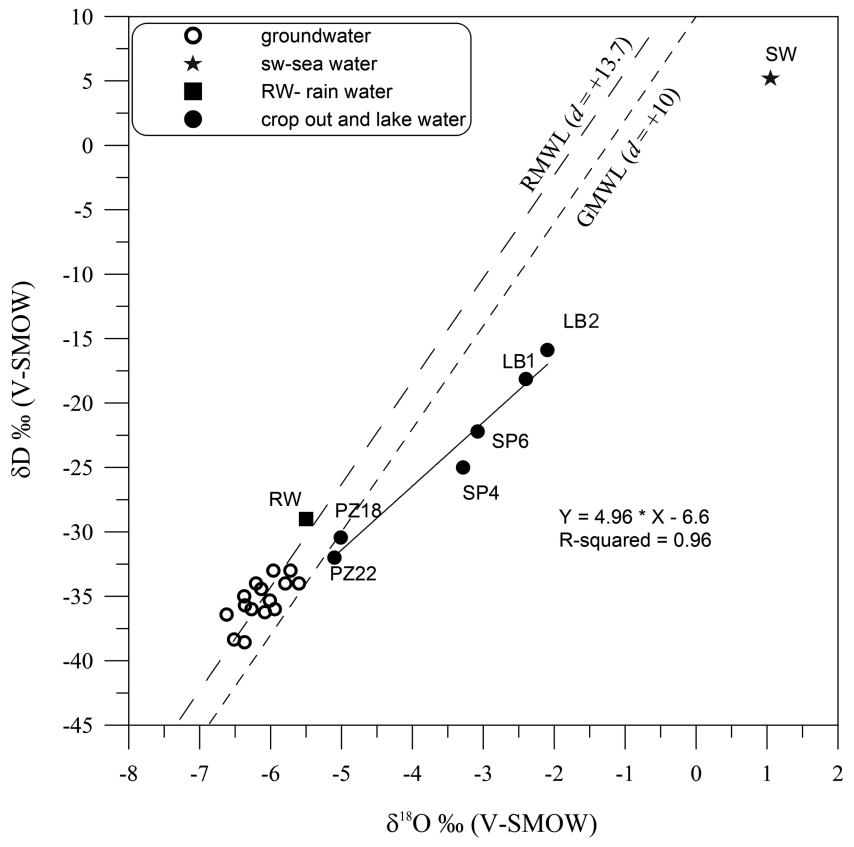

Fig. 5. $\delta^{18} \mathrm{O}$ vs. $\delta \mathrm{D}$ diagram. The regional meteoric water line (RMWL, Chery, 1988; Celle et al., 2004) and the global meteoric water line (GMWL; Craig, 1961) are drawn for comparison. The equation describing the line produced by evaporation effects is also displayed.

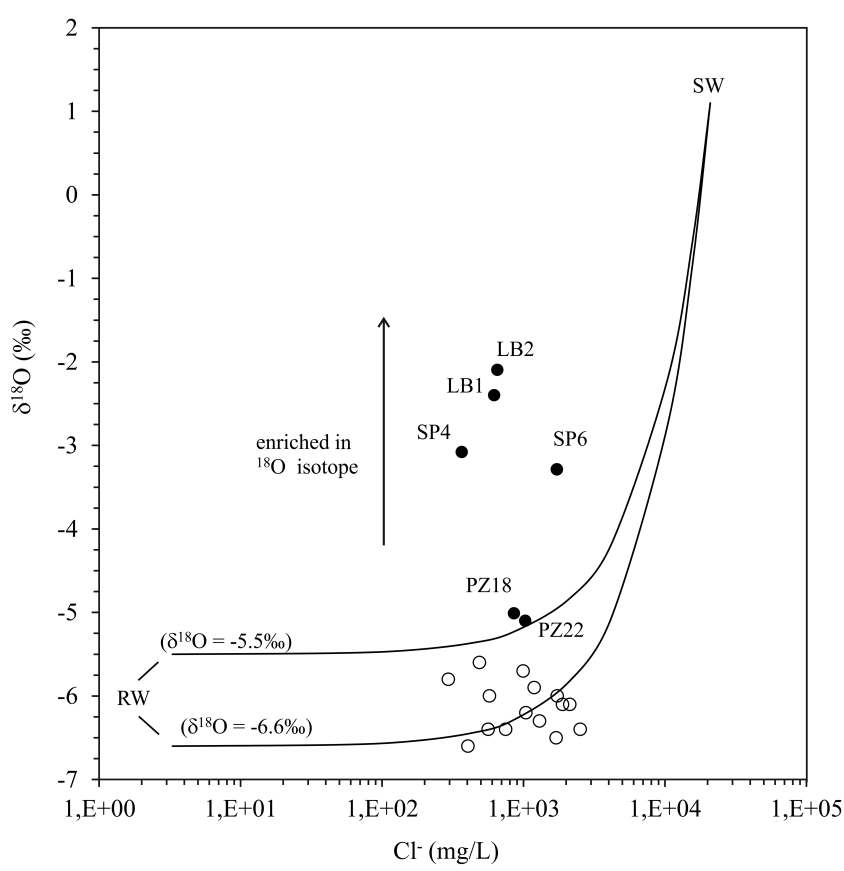

Fig. 6. $\delta^{18} \mathrm{O}$ vs. $\mathrm{Cl} \cdot$ mixing lines between values of rainwater ( $-5.5 \%$, this work, and $-6.6 \%$, mean value by Celle et al., 2004) and seawater (SW, this work) are shown. The symbols are as in Fig. 5 . 


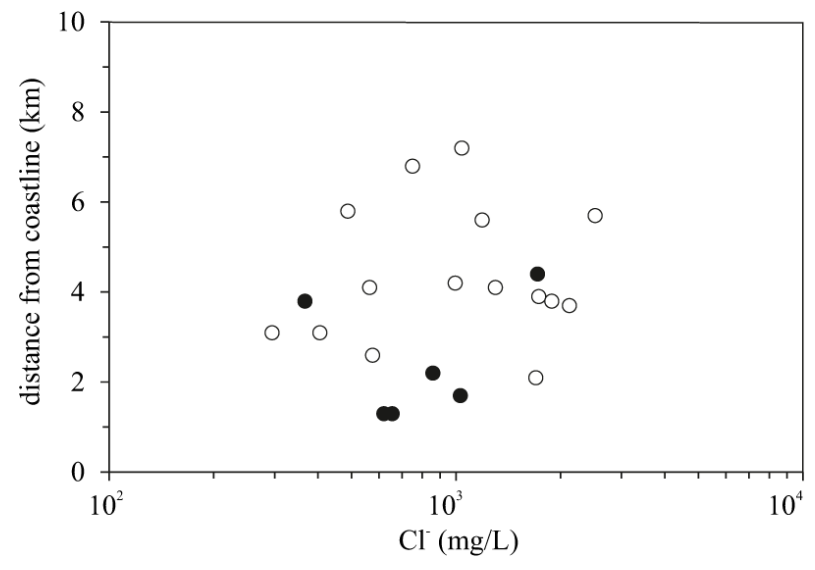

Fig. 7. Binary plot of $\mathrm{Cl}$ vs. distance from coastline.

SP4, which had a value of $26.7^{\circ} \mathrm{C}$. Values of EC ranged from 1240 to $7046 \mu \mathrm{S} \mathrm{cm}^{-1}$. Total dissolved solid (TDS) was typically in the range $1-20 \mathrm{~g} \mathrm{~L}^{-1}$, with the exception of samples SP6 $\left(0.92 \mathrm{~g} \mathrm{~L}^{-1}\right)$ and CS2 $\left(0.98 \mathrm{~g} \mathrm{~L}^{-1}\right)$; consequently, these water samples are brackish according to the classification of Drever (1997).

The concentrations of major ions in the samples are plotted on a Piper diagram in Fig. 3, which identifies the chemical composition of the water as $\mathrm{Na}-\mathrm{Cl}$ type. In the plot of anion concentration (Fig. 3), the samples are roughly distributed along the $\mathrm{HCO}_{3}-\mathrm{Cl}$ boundary between the rainwater and seawater points, and fall close to the $\mathrm{Cl}$ apex. In the plot of ions vs. $\mathrm{Cl}$ (Fig. 4), both the data from the $\mathrm{Na}-\mathrm{Cl}$ water samples and the rainwater-seawater mixing line (hereafter RSML) are plotted to evaluate the extent of possible seawater intrusion. The $\mathrm{Ca} / \mathrm{Cl}, \mathrm{SO}_{4} / \mathrm{Cl}$, and $\mathrm{Sr} / \mathrm{Cl}$ ratios in the water samples are much higher than expected on the basis of simple mixing between rainwater and seawater, which suggests that $\mathrm{SO}_{4}$ dissolution contributes to the increased dissolved component. The $\mathrm{Na} / \mathrm{Cl}$ ratio generally falls above the RSML, suggesting that dissolution of mineral phase(s) may add $\mathrm{Na}$ to the water. The $\mathrm{K} / \mathrm{Cl}$ value is generally below the RSML, suggesting that $\mathrm{K}$ is derived from silicate dissolution only. The variation in the $\mathrm{B}$ content is not correlated with the variation in $\mathrm{Cl}$ content, and the $\mathrm{B} / \mathrm{Cl}$ ratio of the water samples is generally lower to much lower than that of the RSML. Low values of the $\mathrm{B} / \mathrm{Cl}$ ratio are associated with water-rock reactions, since $\mathrm{Cl}$ is preferentially leached with respect to $\mathrm{B}$, and B is adsorbed onto clays (Leybourne and Goodfellow, 2007).

Halogens are particularly useful when investigating the saline component of groundwater (e.g. Boschetti et al., 2011). In the plot of I vs. $\mathrm{Cl}$, the water samples have a scattered distribution, and most are characterized by a high $\mathrm{I} / \mathrm{Cl}$ ratio, which departs significantly from the RSML. Only in the $\mathrm{Br}$ vs. $\mathrm{Cl}$ binary diagram do the water samples follow the RSML, which supports the hypothesis of seawater intrusion. However, it has been stressed previously that the $\mathrm{Br}-\mathrm{Cl}$ relationship in groundwaters is complex, and that the $\mathrm{Br} / \mathrm{Cl}$ ratio
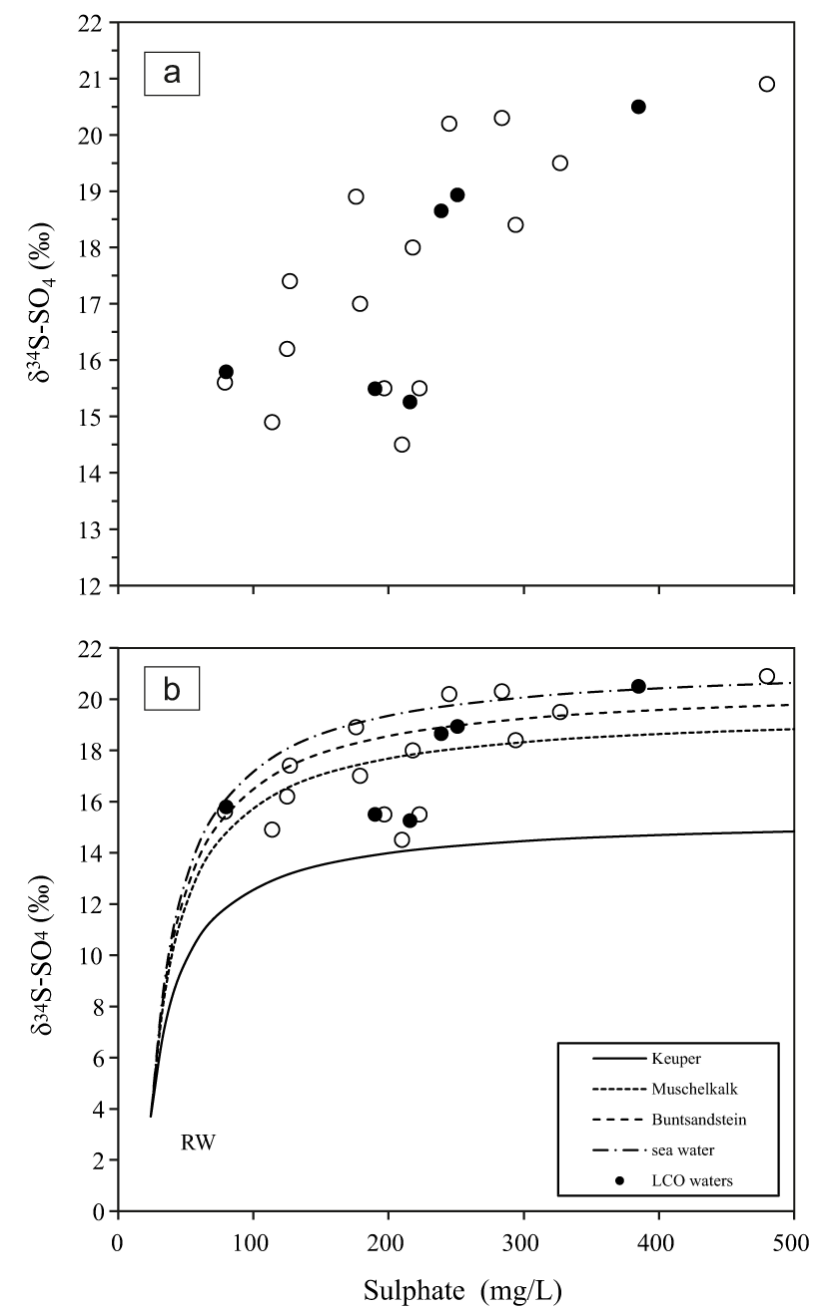

Fig. 8. Plot of $\delta^{34} \mathrm{~S}_{-} \mathrm{SO}_{4}$ and $\mathrm{SO}_{4}$ concentrations for the investigated waters (a). The mixing lines (solid curve) between rainwater and Triassic evaporites are shown (b). The displayed isotopic and chemical data of rainwater $\left(\mathrm{RW}, \delta^{34} \mathrm{~S}=+3.7 \%\right.$; $\left.\mathrm{SO}_{4}=24 \mathrm{mg} \mathrm{L}^{-1}\right)$ refer to September 2011 sampling carried out near the Baratz Lake (see Fig. 1), while the data on Triassic evaporites are from Krouse and Grinenko (1991) and references therein $\left(\delta^{34} \mathrm{~S}=+15.4 \%\right.$ is the mean value for marine sulfates of Keuper; $\delta^{34} \mathrm{~S}=+19.6 \%$ is the mean value for marine sulfates of Muschelkalk and $\delta^{34} \mathrm{~S}=20.6 \%$ o refers to marine sulfates of Buntsandstein). The $\delta^{34} \mathrm{~S}$ value of seawater is $21.6 \%$. The symbols are as in Fig. 5 .

may not be a useful discriminator of marine and non-marine sources of salinity (Leybourne et al., 2007).

Finally, the $\mathrm{NO}_{3}$ concentration of three water samples $\left(\mathrm{PZ2} 4=127 \mathrm{mg} \mathrm{L}^{-1}, \mathrm{PZ26}=74 \mathrm{mg} \mathrm{L}^{-1}, \mathrm{CS} 5=91 \mathrm{mg} \mathrm{L}^{-1}\right)$ exceeds the maximum admissible concentration of $50 \mathrm{~m} \mathrm{~L}^{-1}$ defined under European and Italian laws (Directive 98/83/EC, 1998; D.L. 31/2001，2001). This indicates the need for more detailed future studies concerning environmental factors that influence the water quality. More generally, the lack of any significant (and positive) 


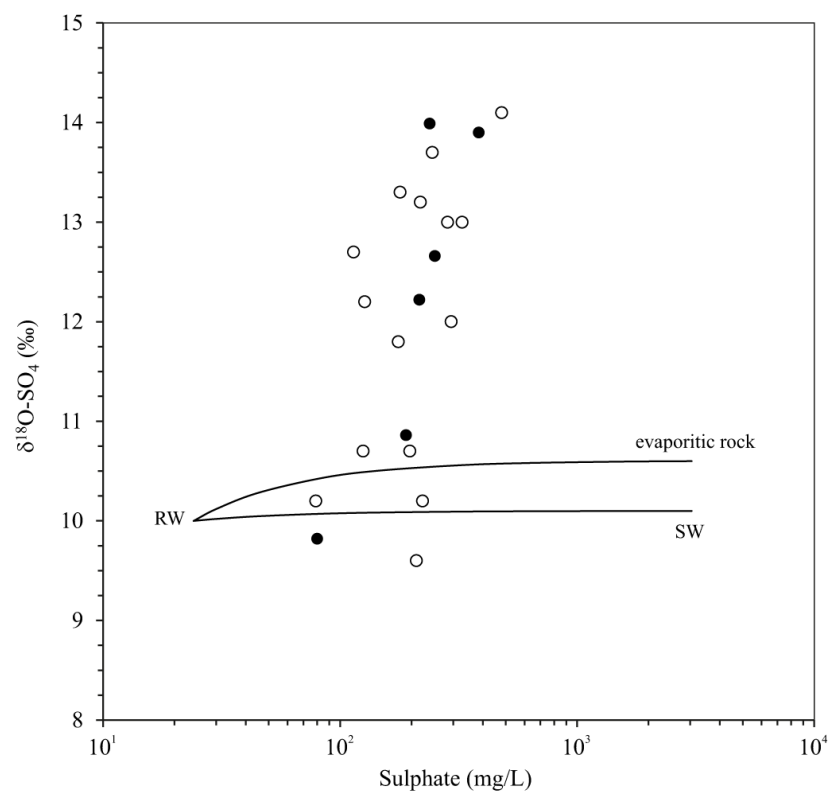

Fig. 9. Plot of $\delta^{18} \mathrm{O}-\mathrm{SO}_{4}$ and $\mathrm{SO}_{4}$ concentrations with mixing lines between rainwater and seawater and rainwater and collected evaporites (mean value of $\delta^{18} \mathrm{O}-\mathrm{SO}_{4}$ is $10.6 \%$ ).

correlation of $\mathrm{NO}_{3}$ with $\mathrm{Cl}(r=-0.26)$ and $\mathrm{SO}_{4}(r=-0.14)$ excludes a nitrate origin for the salinization processes.

\subsection{Isotopic composition of water and dissolved sulfate}

The results of analyses of $\delta^{18} \mathrm{O}, \delta \mathrm{D}$, and oxygen and sulfur isotopes of dissolved $\mathrm{SO}_{4}$ are presented in Table 2. The isotopic compositions of the water samples range from -6.6 to $-2.1 \%$ for $\delta^{18} \mathrm{O}$, and from -39 to $-16 \%$ for $\delta \mathrm{D}$. The seawater sample gave a value of $+1.1 \%$ ofor $\delta^{18} \mathrm{O}$ and $+5 \%$ for $\delta \mathrm{D}$, while the rainwater sample shows values of $-5.5 \%$ for $\delta^{18} \mathrm{O}$ and $29 \%$ for $\delta \mathrm{D}$. Sulfate in the investigated groundwater samples is characterized by positive $\delta^{34} \mathrm{~S}_{-} \mathrm{SO}_{4}$ and $\delta^{18} \mathrm{O}$ $\mathrm{SO}_{4}$ values ranging between +15 and $+21.2 \%$, and between +9 and $+14.1 \%$, respectively. Most of the waters in the $\delta^{18} \mathrm{O}$ vs. $\delta$ D diagram (Fig. 5) plot in a relatively tight cluster between the regional meteoric water line (RMWL; Chery, 1988; Celle et al., 2004) and the global meteoric water line (GMWL; Craig, 1961), which suggests a meteoric origin. Lake water (LB1 and LB2) and outcrop waters (SP6, SP4, $\mathrm{PZ18}, \mathrm{PZ22}$ ) are enriched in the heavy O isotope and form a distinct subset (the LCO waters). These samples fall on a line with a slope of 4.96 (Fig. 5), which is considerably shallower than that of the RMWL (about 8). Such a shallow slope can be produced by evaporation effects (Rozansky and Frohlich, 2001), or the mixing of groundwater and seawater.

In the $\mathrm{Cl}-\delta^{18} \mathrm{O}$ diagram in Fig. 6 , the mixing lines between values of rainwater (RW) and seawater (SW) are plotted with the measured chemical and isotopic data. The iso- topic data from the rainwater endmember is in the range between $-5.5 \%$ (this work) and $-6.6 \%$ (the mean value of Celle et al., 2004). LCO waters do not fall on the mixing lines, which confirms that the enrichment of the heavy $\mathrm{O}$ isotope in these samples is due to evaporation effects (Rozansky and Frohlich, 2001).

The other samples are consistent with a model involving the mixing of rainwater and seawater. However, this assumption is not consistent with (1) the positive linear relationship that exists between the $\mathrm{Cl}$ and $\mathrm{S}$ contents $(r=0.60)$ shown in Fig. 4, (2) the lack of any correlation between distance from the coastline and $\mathrm{Cl}$ content (Fig. 7), and (3) the fact that most of the samples are meteoric in origin (Fig. 5). These considerations, together with the ratios between dissolved ions and $\mathrm{Cl}$ (with the exception of the $\mathrm{Br} / \mathrm{Cl}$ ratio), confirm that the simple mixing of rainwater and seawater can be discounted. The presence of halite within the gypsum deposits, as demonstrated by the XRD analysis, suggests that dissolution of evaporites could be responsible for the high $\mathrm{Cl}$ concentration in the Nurra waters.

\subsection{The origin of salinity}

As previously stated, both the elemental chemistry and isotopic ratios ( $\delta^{18} \mathrm{O}$ and $\delta \mathrm{D}$ values) of the Nurra groundwaters point towards an ambiguous origin for the saline component. The concentration and isotopic composition of dissolved $\mathrm{SO}_{4}$ in groundwater is related to both its source and mechanism of formation, and the $\mathrm{S}$ isotopes of dissolved $\mathrm{SO}_{4}$ can be used to identify the origin of $\mathrm{SO}_{4}$ in water, and the sources of salinity in coastal aquifers (e.g. Schwarcz and Cortecci, 1974; Gaye, 2000; Krouse and Mayer, 2000).

The $\delta^{34}{ }^{3}-\mathrm{SO}_{4}$ values and $\mathrm{SO}_{4}$ concentration (Fig. 8a) show that samples with the highest $\mathrm{SO}_{4}$ concentration have the highest $\delta^{34} \mathrm{~S}$ values but low isotopic variability, whereas samples with lower $\mathrm{SO}_{4}$ concentration have a broader range of isotopic compositions. These data indicate a distribution compatible with a mixing process. Different mixing lines between rainwater and evaporites of different Triassic ages (Buntsandstein, Muschelkalk, and Keuper), and between rainwater and seawater, were calculated and plotted with the measured data (Fig. 8b). The results indicate that the dissolution of evaporitic rocks could be the major source of $\mathrm{SO}_{4}$ in waters of the study area, although for a few samples with higher $\delta^{34} \mathrm{~S}$ values the contribution of seawater cannot be ruled out.

The $\delta^{18} \mathrm{O}_{-} \mathrm{SO}_{4}$ values provide further insights into the sources of $\mathrm{SO}_{4}$. Figure 9 shows $\delta^{18} \mathrm{O}_{-}-\mathrm{SO}_{4}$ values and $\mathrm{SO}_{4}$ concentrations with mixing lines between rainwater and seawater, and between rainwater and collected evaporites (the average $\delta^{18} \mathrm{O}-\mathrm{SO}_{4}$ is $10.6 \%$ ). A few samples fall along the mixing lines, while the majority do not match either mixing model. This situation may be due either to bacterial $\mathrm{SO}_{4}$ reduction (Clark and Fritz, 1997) causing ${ }^{18} \mathrm{O}$ enrichment, or to a re-equilibration of the sulfate ${ }^{18} \mathrm{O}$ isotopes with those in 


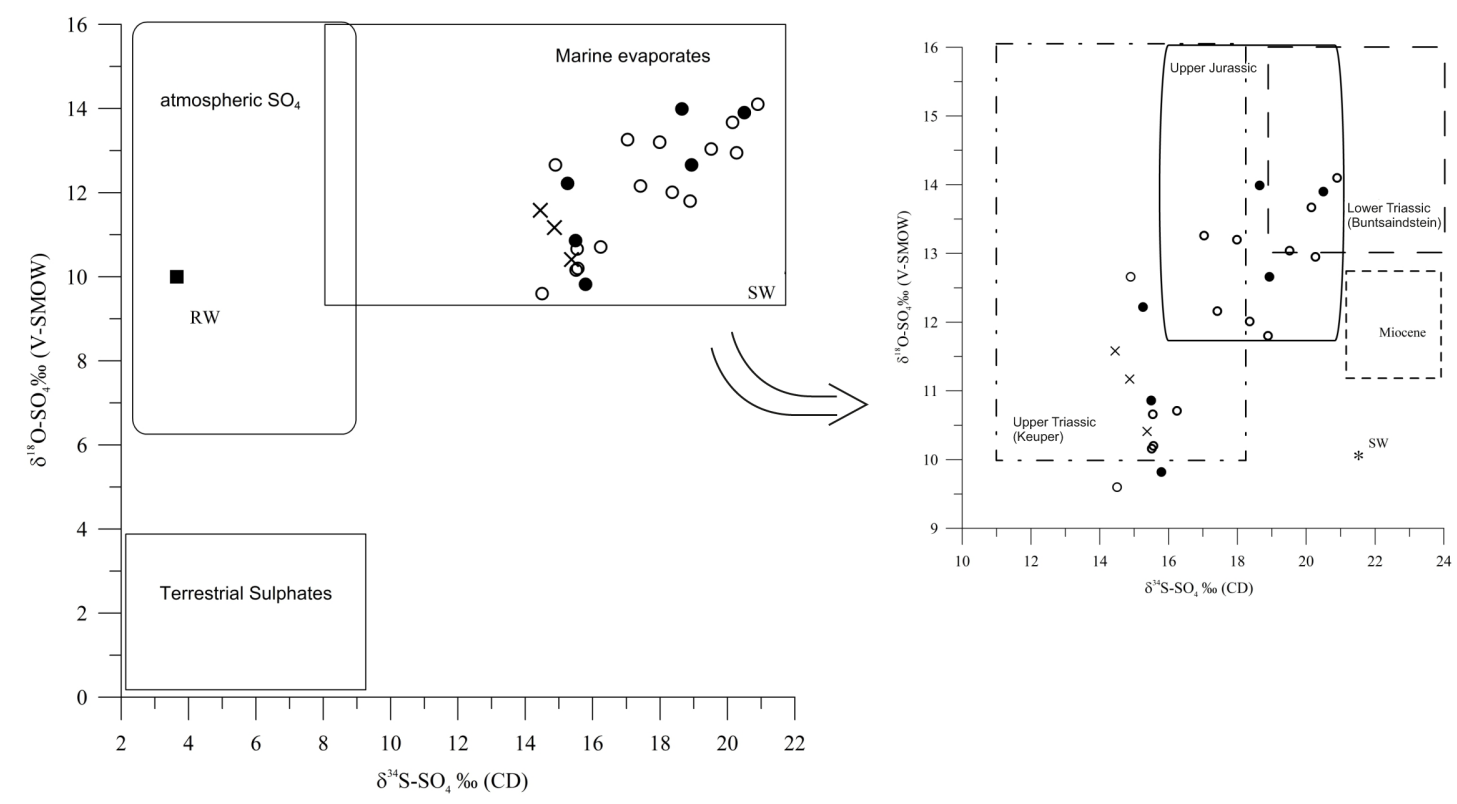

Fig. 10. $\delta^{34} \mathrm{~S}_{-} \mathrm{SO}_{4}$ vs. $\delta^{18} \mathrm{O}-\mathrm{SO}_{4}$. The isotopic composition data of various sources in the diagram are from Clark and Frits (1997). Additional data from Krouse and Grinenko (1991) have been used for the zoom of the diagram. The symbols are as in Fig. 5; the crosses represent the isotopic values of the Nurra evaporitic samples.

the water. The latter reaction would result in the $\delta^{18} \mathrm{O}-\mathrm{SO}_{4}$ values becoming more positive until equilibrium is attained (McKenzie and Truesdell, 1977; Chiba and Sakai, 1985).

However, it is known that the rate of $\mathrm{O}$ isotope exchange between $\mathrm{SO}_{4}$ and water is very slow at low temperatures and normal $\mathrm{pH}$ levels (Chiba and Sakai, 1985). The dualisotope $\left(\delta^{18} \mathrm{O}-\mathrm{SO}_{4}-\delta^{34} \mathrm{~S}_{-} \mathrm{SO}_{4}\right)$ approach has been used with considerable success in both surface water (e.g. Hitchon and Krouse, 1972; Robinson and Bottrell, 1997; Krouse and Mayer, 2000) and groundwaters (Moncaster et al., 2000; Gunn et al., 2006; Li et al., 2006; Bottrell, 2007). It is known that $\mathrm{SO}_{4}$ derived from dissolved evaporites always has positive $\delta^{34} \mathrm{~S}_{-} \mathrm{SO}_{4}$ and $\delta^{18} \mathrm{O}-\mathrm{SO}_{4}$ values that range between +10 and $+30 \%$, and +12 and $+20 \%$, respectively (Claypool et al., 1980), whereas $\mathrm{SO}_{4}$ derived from the oxidation of sulfides or from biogenic emissions may have strongly negative $\delta^{34} \mathrm{~S}$ values (Yang et al., 1997).

The seawater sample has $\delta^{34} \mathrm{~S}$ and $\delta^{18} \mathrm{O}$ values similar to those of dissolved marine evaporates (Krouse and Mayer, 2000). In Fig. $10\left(\delta^{34} \mathrm{~S}_{-} \mathrm{SO}_{4}\right.$ vs. $\left.\delta^{18} \mathrm{O}_{-} \mathrm{SO}_{4}\right)$, all investigated samples, including the LCO waters, fall within the marine evaporites field (Clark and Fritz, 1997). Moreover, most of the samples show $\delta^{18} \mathrm{O}$ values higher than the seawater endmember. A few samples are characterized by isotopic values consistent with the Upper Triassic evaporites (from +14.4 to $+15.4 \%$ or for $\delta^{34} \mathrm{~S}_{-\mathrm{SO}_{4}}$ values and from +10.4 to $+11.6 \%$ o for $\delta^{18}{\mathrm{O}-\mathrm{SO}_{4}}_{4}$ values), while other samples show higher values. The enrichment in measured ${ }^{18} \mathrm{O}$ and ${ }^{34} \mathrm{~S}$ may reflect fractionation due to bacterial $\mathrm{SO}_{4}$ reduction (Clark and Fritz, 1997) or a heavier isotopic source. The lack of $\mathrm{H}_{2} \mathrm{~S}$, the high Eh values, and the presence of dissolved $\mathrm{O}_{2}$ (Ghiglieri et al., 2009, and references therein) exclude the possibility that these waters were affected by microbial $\mathrm{SO}_{4}$ reduction. Therefore, a contribution from an isotopically heavier source is conceivable, possibly due to interaction with the Muschelkalk and/or Buntsandstein evaporite deposits (Fig. 10). In addition, the saturation indexes for gypsum, anhydrite, halite, and sylvite are less than one (Table 2), suggesting that the dissolution of soluble salts is an ongoing process. Finally, this in turn suggests that the salinization of the Nurra region, in a climatic regime that is evolving towards drier conditions, is a phenomenon that could be dramatically accentuated in the near future.

\section{Summary}

The Nurra aquifers of Jurassic and Triassic age contain brackish $\mathrm{Na}-\mathrm{Cl}$ waters and have $\mathrm{Cl}$ contents of up to $2025 \mathrm{mg} \mathrm{L}^{-1}$. The ratios between dissolved ions and $\mathrm{Cl}$, with the exception of the $\mathrm{Br} / \mathrm{Cl}$ ratio, are not those expected from the simple mixing of rainwater and seawater. The $\delta^{18} \mathrm{O}$ and $\delta \mathrm{D}$ data indicate that most of the waters fall between the regional meteoric water line and the global meteoric water line, supporting the conclusion that they are meteoric in origin. Due to evaporation, the LCO waters were enriched in ${ }^{18} \mathrm{O}$. An important consequence of the meteoric origin of the studied $\mathrm{Na}$-Cl-type water is that the $\mathrm{Br} / \mathrm{Cl}$ ratio, extensively used to assess the origin of salinity in fresh water, and that in the present case is compatible with a seawater-rainwater mixing (thus erroneously supporting the hypothesis of a marine 
intrusion), should be used with care also in near-coastal carbonate aquifers.

A dual-isotope approach, based on $\delta^{34} \mathrm{~S}$ and $\delta^{18} \mathrm{O}$ in dissolved $\mathrm{SO}_{4}$, proved useful in assessing the origin of salinity in the $\mathrm{Na}-\mathrm{Cl}$ brackish water hosted in some of the aquifers of northwestern Sardinia. All of the samples analysed here had isotopic compositions within the range of marine evaporites. A few samples were characterized by isotopic values consistent with those of the Upper Triassic (Keuper) Nurra evaporites that, in this study, were analysed for the first time for their isotopic and mineralogical composition. Others samples had a heavier isotopic composition, consistent with interaction with the isotopic composition of older Triassic sediments (Muschelkalk and Buntsandstein) that also occur in the area. Overall, and in accordance with the geological and lithological features of the study area, the $\delta^{34} \mathrm{~S}$ and $\delta^{18} \mathrm{O}$ values in dissolved $\mathrm{SO}_{4}$ suggest that water-rock interaction is responsible for the composition of the $\mathrm{Na}-\mathrm{Cl}$ brackish water. The dissolution of evaporites also contributed to the high $\mathrm{Cl}$ content, as halite was detected in the gypsum deposits. Finally, the waters are undersaturated with respect to the more soluble salts, which indicates that, in a climate evolving towards semi-arid conditions, the salinization process could intensify significantly in the near future.

Acknowledgements. The paper was financially supported by Banco di Sardegna Foundation and G. Mongelli and M. Paternoster grants (RIL 2009). Many thanks to A. Bonomo for her support during fieldwork. We greatly appreciate comments and suggestions of M. Nathenson and G. Ghiglieri, which contribute to improving this paper.

Edited by: A. D. Reeves

\section{References}

Boschetti, T., Toscani, L., Shouakar-Stash, O., Iacumin, P., Venturelli, G., Mucchino, C., and Frape, S. C.: Salt Waters of the Northern Apennine Foredeep Basin (Italy): Origin and Evolution, Aquat. Geochem., 17, 71-108, doi:10.1007/s10498-0109107-y, 2011.

Bottrell, S. H.: Stable isotopes in aqueous sulfate as tracers of natural and contaminant sulphate sources: a reconnaissance study of the Xingwen karst aquifer, Sichuan, China, in: Natural and Anthropogenic Hazards in Karst Areas: Recognition, Analysis and Mitigation, 279, Geological Society, London, Special Publication, 123-135, 2007.

Bouchaou, L., Michelot, J. L., Vengosh, A., Hsissou, Y., Qurtobi, M., Gaye, C. B., Bullen, T. D., and Zuppi, G. M.: Application of multiple isotopic and geochemical tracers for recharge, salinization, and residence time of water in the Souss-Massa aquifer, southwest of Morocco, J. Hydrol., 352, 267-287, 2008.

Carmignani, L., Funedda, A., Oggiano, G., and Pasci, S.: Tectonosedimentary evolution of southwest Sardinia in the Paleogene: Pyrenaic or Apenninic Dynamic?, Geodin. Acta, 17, 275287, 2004.
Celle, H., Gonfiantini, R., Travi, Y., and Sol, B.: Oxygen-18 variations of rainwater during precipitation: application of the Rayleigh model to selected rainfalls in Southern France, J. Hydrol., 289, 165-177, doi:10.1016/j.jhydrol.2003.11.017, 2004.

Cherry, L.: Essai de caractérisation géochimique et isotopique d'émergences de circulations profondes dans deux types de massifs granitiques: Auriat (Creuse) et La Sposata (Corse). Ph.D. dissertation, Université de Paris-Sud, Orsay, 1988.

Chiba, H. and Sakai, H.: Oxygen isotope exchange between dissolved sulfate and water at hydrothermal temperatures, Geochim. Cosmochim. Ac., 49, 993-1000, 1985.

Clark, I. and Fritz, P.: Environmental Isotopes in hydrogeology, Lewis Publications, Boca Raton, p. 328, 1997.

Claypool, G. E., Holser, W. T., Kaplan, Y. R., Sakai, H., and Zak, I.: The age of sulfur and oxygen isotopes in marine sulfate and their mutual interpretation, Chem. Geol., 28, 199-260, 1980.

Coleman, M. L., Stephen, T. J., Durham, J. J., Rousse, J. B., and Moore, G. R.: Reduction of water with zinc for hydrogen analysis, Ann. Chem., 54, 993-995, 1982.

Combes, P. J., Oggiano, G., and Temussi I.: Géodynamique des bauxites sardes, typologie, genèse et contrôle paléotectonique, C. R. Acad. Sci., 316, 403-409, 1993.

Craig, H.: Isotopic variations in meteoric waters, Science, 133, 1702-1703, 1961.

Directive 98/83/EC on the quality of water intended for human consumption. Official Journal of the European Communities, available at: http://eur-lex.europa.eu/LexUriServ/LexUriServ.do?uri= CELEX:31998L0083:en:NOT, 3 November, 1998.

D.L.: 31/2001: Decreto legislativo 2 febbraio 2001, n. 31, attuazione della direttiva 98/83/CE relativa alla qualità delle acque destinate al consumo umano. Gazzetta Ufficiale n. 52 del 3 March, 2001.

Drever, J. I.: The Geochemistry of Natural Waters. Prentice Hall, Englewood Cliffs, p. 245, 1997.

El Yaouti, F., El Mandour, A., Khattach, D., Benavente, J., and Kaufmann, O.: Salinization processes in the unconfined aquifer of Bou-Areg (NE Morocco): a geostatistical, geochemical and tomographic study, Appl. Geochem., 24, 16-31, 2009.

Epstein, S., and Mayeda, T. K.: Variations of the 18O/16O ratios in natural waters, Geochim. Cosmochim. Ac., 4, 213-224, 1953.

Faye, S., Maloszewki, P., Stichler, W., Trimborn, P., Cisse Faye, S., and Bécaye Gaye, C.: Groundwater salinization in the saloum (Senegal) delta aquifer: minor elements and isotopic indicators, Sci. Total Environ., 343, 243-259, 2005.

Funedda, A., Oggiano, G., and Pasci, S.: The Logudoro basin: a key area for the Tertiary tectono-sedimentary evolution of North Sardinia, Boll. Soc. Geol. It., 119, 31-38, 2000.

Gattacceca, J. C., Vallet-Coulomb, C., Mayer, A., Claude, C., Radakovitch, O., Conchetto, E., and Hamelin, B.: Isotopic and geochemical characterization of salinization in the shallow aquifers of a reclaimed subsiding zone: the southern venice lagoon coastland, J. Hydrol., 378, 46-61, 2009.

Gaye, C. B.: Isotope techniques for monitoring ground water salinization. In editor's Message, Hydrog. J., 9, 217-218, 2000.

Ghiglieri, G., Barbieri, G., and Vernier, A.: Studio sulla gestione sostenibile delle risorse idriche: dall' analisi conoscitiva alle strategie di salvaguardia e tutela, ENEA, Rome, 550 pp., 2006.

Ghiglieri, G., Oggiano, G., Fidelibus, M. D., Alemayehu, T., Barbieri, G., and Vernier, A.: Hydrogeology of the Nurra region, Sardinia (Italy): basement -cover influences on groundwater 
occurrence and hydrogeochemistry, Hydrogeol. J., 17, 447-466, 2009.

Ghiglieri, G., Carletti, A., and Pittalis, D.: Analysis of salinization in the coastal carbonate aquifer of Porto Torres (NW Sardinia, Italy), J. Hydrol., 432-433, 43-51, doi:10.1016/j.jhydrol.2012.02.016, 2012.

Gonfiantini, R., Stichler, W., and Rozanski, K.: Standards and intercomparison materials distributed by the IAEA for stable isotope measurements, in: Reference and Intercomparison Materials for Stable Isotopes of Light Elements, TECDOC 825, I.A.E.A., Vienna, 13-29, 1995.

Gunn, J., Bottrell, S. H., Lowe, D. J., and Worthington, S. R. H.: Deep groundwater flow and geochemical processes in limestone aquifers: evidence from thermal waters in Derbyshire, England, UK, Hydrogeol. J., 14, 868-881, 2006.

Hitchon, B. and Krouse, H. R.: Hydrogeochemistry of the surface waters of the Mackenzie River drainage basin, Canada: III. Stable isotopes of oxygen, carbon and sulphur, Geochim. Cosmochim. Ac., 36, 1337-1357, 1972.

Krouse, H. R. and Grinenko, V. A.: Stable isotopes. Natural and Anthropogenic sulphur in the environment. SCOPE 43, John Wiley and Sons. Chichester, New Jork, Brisbane, Toronto and Singapore, p. 440, 1991.

Krouse, H. R. and Mayer, B.: Sulphur and oxygen isotopes in sulphate, in: Environmental Tracers in Subsurface Hydrology, edited by: Cook, P. G. and Herczeg, A. L., Kluwer Academic, 195-231, 2000.

Leybourne, M. I. and Goodfellow, W. D.: $\mathrm{Br} / \mathrm{Cl}$ ratios and $\mathrm{O}, \mathrm{H}, \mathrm{C}$, and $\mathrm{B}$ isotopic constraints on the origin of saline waters from eastern Canada, Geochim. Cosmochim. Ac., 71, 2209-2223, 2007.

Li, X., Masuda, H., Kusakabe, M., Yanagisawa, F., and Zeng, H.: Degradation of groundwater quality due to anthropogenic sulfur and nitrogen contamination in the Sichuan Basin, China, Geochem. J., 40, 309-332, 2006.

Malinverno, A. and Ryan, W. B. F.: Extension in the Tyrrhenian Sea and shortening in the Apennines as a result of arc migration driven by sinking of the lithosphere, Tectonics, 5, 227-245, 1986.

Mameli, P., Mongelli, G., Oggiano, G., and Dinelli, E.: Geological, geochemical and mineralogical features of some bauxite deposits from Nurra (Western Sardinia, Italy): Insights on conditions of formation and parental affinity, Int. J. Earth Sci., 96, 887-902, 2007.

McKenzie, W. F. and Truesdell, A. H.: Geothermal reservoir temperatures estimated from the oxygen isotope compositions of dissolved sulfate and water from hot springs and shallow drillholes, Geoth., 5, 51-61, 1977.
Moncaster, S. J., Bottrell, S. H., Tellam, J. H., Lloyd, J. W., and Konhauser, K. O.: Migration and attenuation of agrochemical pollutants: insights from isotopic analysis of groundwater sulphate, J. Contam. Hydrol., 43, 147-163, 2000.

Mongelli, G., Mameli, P., Oggiano, G., and Sinisi, R.: Messinian palaeoclimate and palaeo-environment in the western Mediterranean realm: insights from the geochemistry of continental deposits of NW Sardinia (Italy), Int. Geol. Rev., 54, 971-990, 2012.

Oggiano, G., Funedda, A., Carmignani, L., and Pasci, S.: The Sardinia-Corsica microplate and its role in the Northern Apennine Geodynamics: new insights from the Tertiary intraplate strike-slip tectonics of Sardinia, Ital. J. Geosci., 128, 527-539, 2009.

Pecorini, G.: Le Clavatoracee del "Purbeckiano" di Cala d'Inferno nella Nurra di Alghero (Sardegna nord-occidentale), Boll. Soc. Sarda Sc. Nat., 5, 1-14, 1969.

Petalas, C. and Lambrakis, N.: Simulation of intense salinization phenomena in coastal aquifers - the case of the coastal aquifers of Thrace, J. Hydrol., 324, 51-64, 2006.

Robinson, B. W. and Bottrell, S. H.: Discrimination of sulfur sources in pristine and polluted New Zealand river catchments using stable isotopes, Appl. Geochem., 12, 305-319, 1997.

Rozanski, K. and Fröhlich, K.: Surface water, in: Environmental isotopes in the hydrological cycle, 3, edited by: Mook, W. G., UNESCO/IAEA, Paris, 2001.

Schwarcz, H. P. and Cortecci, G.: Isotopic analyses of spring and stream water $\mathrm{SO}_{4}$ from the Italian Alps and Apennines, Chem. Geol., 13, 285-294, 1974.

Sdao, F., Parisi, S., Kalisperi, D., Pascale, S., Soupios, P., LydakisSimantiris, N., and Kouli, M.: Geochemistry and quality of the groundwater from the karstic and coastal aquifer of Geropotamos River Basin at north-central Crete, Greece, Environ. Earth Sci., 67, 1145-1163, 2012.

Thomas, B. and Gennesseaux, M.: A two stage rifting in the basin of Corsica-Sardinia strait, Mar. Geol., 72, 225-239, 1986.

Yanagisawa, F. and Sakai, H.: Thermal decomposition of barium sulfate-vanadium pentoxid-silica glass mixtures for preparation of sulfur dioxide in sulfur isotope ratio measurements, Anal. Chem., 55, 985-987, 1983.

Yang, W., Spencer, R. J., and Krouse, H. R.: Stable isotope compositions of waters and sulfate species therein, Death Valley, California, USA, Implications for in?ow and sulfate sources, and arid basin climate, Earth Planet. Sc. Lett., 147, 69-82, 1997. 